\title{
Association of single nucleotide polymorphisms in the MVP gene with platinum resistance and survival in patients with epithelial ovarian cancer
}

\author{
YA-NAN ZHAO ${ }^{1}$, DONG-NING HE ${ }^{1}$, YA-DI WANG ${ }^{2}$, JUN-JIE LI ${ }^{3}$ and MIN-WEN HA ${ }^{1}$ \\ ${ }^{1}$ Department of Oncology, The First Affiliated Hospital of Liaoning Medical University; \\ ${ }^{2}$ Department of Oncology, The Third Affiliated Hospital of Liaoning Medical University; \\ ${ }^{3}$ Department of Thoracic Surgery, The First Affiliated Hospital of Liaoning Medical University, \\ Jinzhou, Liaoning 121000, P.R. China
}

Received December 29, 2014; Accepted January 18, 2016

DOI: 10.3892/ol.2016.4311

\begin{abstract}
The human major vault protein (MVP) has been linked to the development of multidrug resistance in cancer cells, and overexpression of MVP has been observed in ovarian cancer tissues. The aim of the present study was to investigate the association between single nucleotide polymorphisms (SNPs) in the MVP gene and the tumor response to platinum-based chemotherapy and survival of patients affected by epithelial ovarian cancer (EOC), in addition to confirm whether tetra-primer amplification-refractory mutation system (ARMS)-polymerase chain reaction (PCR) is an accurate genotyping method. For this purpose, two polymorphisms in the MVP gene, namely reference SNP (rs)1057451 and rs4788186, were selected from the data obtained by the International haplotype map (HapMap) Project regarding Chinese Han population, and were evaluated by tetra-primer ARMS-PCR. Upon validation by DNA sequencing, the association of these polymorphisms with platinum resistance, progression-free survival (PFS) and overall survival (OS) in patients with EOC was assessed. The results of tetra-primer ARMS-PCR were in agreement with those derived from DNA sequencing. No significant differences were observed between platinum-sensitive and platinum-resistant cohorts in terms of allele and genotype distribution of these two polymorphisms in the MVP gene, which were not associated with PFS or OS. However, a trend toward prolonged PFS was observed in patients carrying the heterozygous AG allele at the rs4788186 locus. These results suggest that rs1057451 and rs4788186 variants in the MVP gene are not associated with
\end{abstract}

Correspondence to: Professor Min-Wen Ha, Department of Oncology, The First Affiliated Hospital of Liaoning Medical University, No. 2, Section 5, Renmin Street, Guta, Jinzhou, Liaoning 121000, P.R. China

E-mail: minwenha@outlook.com

Key words: epithelial ovarian cancer, MVP, single nucleotide polymorphism, platinum resistance, survival, tetra-primer ARMS-PCR favorable therapeutic response to platinum or longer survival in Chinese Han patients affected by EOC. In addition, the data of the present study confirm that tetra-primer ARMS-PCR is a trustworthy and economical genotyping method.

\section{Introduction}

Ovarian cancer remains the leading cause of mortality due to gynecological cancer in the world (1). At present, platinum-based chemotherapy following surgery represents the standard therapy for those cases of ovarian cancer at advanced and high-risk early stages (2-5). A total of $70 \%$ of patients with ovarian cancer demonstrate a response to cytoreductive surgery followed by platinum-based chemotherapy (6); however, the majority of these patients will experience relapse. Thus, subsequent treatments are moderate in curative effect and typically short in duration (7).

Tumor cells that are resistant to a particular chemotherapeutic drug are also often observed to be not sensitive to a variety of structurally and functionally unrelated chemotherapeutic drugs (8). This phenomenon is known as multidrug resistance (MDR) (9). The mechanisms of MDR remain unclear, but it may be attributed to increased drug efflux (10-12), enhanced DNA damage repair $(13,14)$, resistance to apoptosis $(15,16)$, self-renewing tumor stem cells (17) and tumor microenvironment (18-20). Since 1995, when major vault protein (MVP) was identified to be identical to lung resistance-related protein (21), numerous studies have investigated the role of MVP in MDR (22-24).

MVP is the main component of vault, which contains two additional proteins known as vault poly-(adenosine diphosphate-ribose) polymerase and telomerase-associated protein 1 , in addition to several small untranslated vault RNAs (25-28). The amino acid sequence of MVP is highly conserved among eukaryotic cells (21). MVP is present in normal tissues, including bronchus, digestive tract and macrophages, and in malignant cells, including acute myeloid leukemia, ovarian cancer and colon carcinoma (29). The high degree of conservation and ubiquitous expression of MVP suggest that this protein exerts crucial cellular functions (29). Increasing 
evidence from previous studies has demonstrated that high messenger (m)RNA and protein levels of MVP are associated with resistance to antineoplastic agents and reduced survival in certain types of cancer, including ovarian cancer (22,30-32).

Single nucleotide polymorphisms (SNPs) are the most common type of genetic variation among the human population, and are often associated with inter-individual diversity in various malignancies regarding the patient's susceptibility to disease, drug response, toxicity and survival (33-36). However, to the best of our knowledge, the role of MVP SNPs in platinum resistance and prognosis of patients with ovarian cancer has not been reported thus far. Therefore, in order to assess whether SNPs in the MVP gene were associated with platinum resistance and survival in epithelial ovarian cancer (EOC), two polymorphisms were selected from the genotype data of Chinese Han population derived from the phase II International (haplotype map) HapMap Project (date of access to the database, August 14, 2014). The specific MVP genotypes were subsequently identified in the patients with EOC recruited for the present study, and the associations between these genotypes and the response to platinum-based regimens, progression-free survival (PFS) and overall survival (OS) exhibited by these patients were analyzed. Furthermore, the results of the present study confirmed the feasibility of tetra-primer amplification-refractory mutation system (ARMS)-polymerase chain reaction (PCR) as a genotyping tool.

\section{Materials and methods}

Patients and clinical data. A total of 116 Chinese Han female patients with EOC and Karnofsky performance status score $\geq 70$ were recruited between June 2005 and February 2012, and treated at the Department of Oncology of The First Affiliated Hospital of Liaoning Medical University (Jinzhou, China). Written informed consent was obtained from all the patients included in the study, which was approved by the Ethics Review Committee of The First Affiliated Hospital of Liaoning Medical University. Following surgery, the patients were intravenously treated with taxol $\left(135 \mathrm{mg} / \mathrm{m}^{2} \mathrm{~d} 1\right)$ or taxetere $\left(75 \mathrm{mg} / \mathrm{m}^{2} \mathrm{~d} 1\right)$ and cisplatin (30 mg d2-4) or carboplatin (AUC 4-6 d2) at three or four weeks intervals for at least 3 cycles.

Follow-up examinations. Follow-up examinations were performed every 3 months or when patients presented with symptoms of progression and consulted a doctor. The examinations included pelvic examination, determination of the levels of cancer antigen (CA)125 in serum and pelvic computed tomography (CT) scanning. In addition, liver ultrasonography, thoracic or abdominal CT scanning and brain magnetic resonance imaging were conducted when necessary. Patients who exhibited persistent or progressive disease during the treatment or recurred within 6 months of completion of the platinum-based chemotherapy were defined as platinum-resistant (37). By contrast, patients who exhibited disease progression later than 6 months upon completion of the platinum-based therapy were considered to be platinum-sensitive. PFS was calculated as the duration, in months, from the date of histological diagnosis to the first sign of recurrence detected by physical examination, CA125 evaluation or radiographic inspection. OS was calculated as the duration, in months, from the date of histological diagnosis to mortality or last follow-up.
DNA extraction. Prior to the initiation of chemotherapy, genomic DNA was obtained from peripheral venous blood using TIANamp Blood DNA Kit (catalog no., DP318; Tiangen Biotech Co., Ltd., Beijing, China), according to the manufacturer's protocol. The purity and concentration of the extracted DNA were assessed by spectrophotometry using the BioPhotometer Plus (Eppendorf, Hamburg, Germany). The method yielded DNA of relatively high concentration $($ median $=39.3 \mu \mathrm{g} / \mathrm{ml}$, range $=18.4-60.5 \mu \mathrm{g} / \mathrm{ml})$ and purity (median absorbance $(\mathrm{A})_{200} / \mathrm{A}_{280}$ ratio $=1.81$, range $\left.=1.46-2.37\right)$. The extracted DNA was stored at $-80^{\circ} \mathrm{C}$ until further use.

Genotyping. The tagging SNPs reference SNP (rs)1057451, rs4788186 and rs2288043 were selected from the genotype data of Chinese Han population derived from the International HapMap Project (HapMap Data Release 24/phase II Nov08, on National Center for Biotechnology Information B36 assembly, database SNP b126) to capture the maximum variation based on $r^{2} \geq 0.8$ and minor allele frequency $\geq 0.05$. Genotyping of the selected SNPs was performed by the cost-effective method of tetra-primer ARMS-PCR, as proposed by Ye et al (38). PCR was conducted in a total volume of $20 \mu \mathrm{l}$, which contained $1 \mu \mathrm{l}$ template DNA, $0.5 \mu l$ each of the four primers (the concentration of the working solution was $10 \mu \mathrm{M}$; primers were designed by Primer Premier 5.0, Premier Biosoft International, Palo Alto, CA, USA), $10 \mu 1$ 2XTaq PCR MasterMix (containing $0.1 \mathrm{U} / \mu \mathrm{l}$ Taq polymerase, $500 \mu \mathrm{M}$ each deoxynucleotide, $20 \mathrm{mM}$ Tris- $\mathrm{HCl}$ $\mathrm{pH} 8.3,100 \mathrm{mM} \mathrm{KCl}, 3 \mathrm{mM} \mathrm{MgCl}{ }_{2}$ and other stabilizers and enhancers; catalog no., KT203; Tiangen Biotech Co., Ltd.) and $7 \mu \mathrm{l}$ double-distilled (dd) $\mathrm{H}_{2} \mathrm{O}$. Table I indicates the primer sets used for the amplification of the three aforementioned polymorphisms. The reaction was performed on 2720 Thermal Cycler (Applied Biosystems, Foster City, CA, USA) under the following conditions: a denaturation step at $95^{\circ} \mathrm{C}$ for $5 \mathrm{~min}$, followed by 30 cycles of $95^{\circ} \mathrm{C}$ for $30 \mathrm{sec}, 30 \mathrm{sec}$ at the corresponding annealing temperature (as described in Table I) and $30 \mathrm{sec}$ at $72^{\circ} \mathrm{C}$, and a final extension at $72^{\circ} \mathrm{C}$ for $10 \mathrm{~min}$. All PCR products were added to $2 \%$ agarose gel (catalog no., 5260; Takara Biotechnology Co., Ltd., Dalian, China) which was stained with $1 \mu \mathrm{l} / 10 \mathrm{ml}$ DuRed (catalog no., 009-500; Fanbo Biochemicals Co. Ltd., Beijing, China). DL1,000 DNA marker (catalog no., 3591Q; Takara Biotechnology Co., Ltd.) was also added into the well as a reference for the targeted DNA bands. The products and marker were defined by agarose gel electrophoresis with the PowerPac ${ }^{\mathrm{TM}} 3000$ system (Bio-Rad Laboratories, Inc., Hercules, CA, USA), and subsequently visualized using the 2500R Gel Imaging System (Tanon Science and Technology Co., Ltd., Shanghai, China).

Genotyping validation. To validate the accuracy of the results obtained by tetra-primer ARMS-PCR analysis, a number of representative samples of each genotype were selected, and conventional PCR was conducted in a total volume of $20 \mu \mathrm{l}$, which contained $2 \mu \mathrm{l}$ template DNA, $1 \mu \mathrm{l}$ each outer primer,

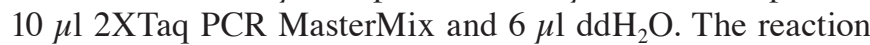
was performed on a 2720 Thermal Cycler (Applied Biosystems) with a denaturation step at $95^{\circ} \mathrm{C}$ for $5 \mathrm{~min}, 30$ cycles of $95^{\circ} \mathrm{C}$ for $30 \mathrm{sec}$, the corresponding annealing temperature (described in Table I) for $30 \mathrm{sec}$, and $72^{\circ} \mathrm{C}$ for $30 \mathrm{sec}$, followed by a final extension at $72^{\circ} \mathrm{C}$ for $10 \mathrm{~min}$. The PCR products were then sequenced by the Sanger method [reagents included the following: BigDye ${ }^{\circledR}$ 
Table I. PCR primers and conditions.

\begin{tabular}{|c|c|c|c|c|}
\hline Polymorphism & PCR primer, 5'-3' & $\mathrm{Ta},{ }^{\circ} \mathrm{C}$ & Amplicon size, bp & Sequencing primer, 5'-3' \\
\hline \multicolumn{5}{|l|}{ rs 1057451} \\
\hline $\mathrm{F}$ inner primer ( $\mathrm{G}$ allele $)$ & ATTGATGAAGATCAGGGaTG & 54 & 288 (G allele) & TTCCACTTGTCСТСССТC \\
\hline $\mathrm{R}$ inner primer ( $\mathrm{T}$ allele) & CAGGAACCAGGCTTCAaA & & 420 (T allele) & \\
\hline F outer primer & ATTGAGGGCACTTAACACTAC & & 671 (outer primers) & \\
\hline $\mathrm{R}$ outer primer & GACTCAGGAATTGCCAACA & & & \\
\hline \multicolumn{5}{|l|}{ rs4788186 } \\
\hline $\mathrm{F}$ inner primer ( $\mathrm{G}$ allele) & TAAAGCATAGGAAAGAGtCG & 55 & 449 ( $\mathrm{G}$ allele) & F outer primer \\
\hline $\mathrm{R}$ inner primer (A allele) & TGAGCTGTGTCTATGTTCaCT & & 211 (A allele) & \\
\hline F outer primer & АСССТАСССТTGCTCACA & & 620 (outer primers) & \\
\hline $\mathrm{R}$ outer primer & AGCCCATCCTGACCTTAC & & & \\
\hline \multicolumn{5}{|l|}{ rs2288043 } \\
\hline F inner primer (A allele) & CATAGATGCCCTCGTTCgCA & 55 & 292 (A allele) & F outer primer \\
\hline $\mathrm{R}$ inner primer ( $\mathrm{G}$ allele) & GCCAGGCCATCCCTCTAGtC & & 80 (G allele) & \\
\hline F outer primer & СТСАСТСССАGCСАTTAССТTТC & & 333 (outer primers) & \\
\hline $\mathrm{R}$ outer primer & GGCACTGACCCTAACCTCACG & & & \\
\hline
\end{tabular}

The lower-case letter in the inner primer sequences represents a deliberate mismatch base, which was introduced at position -2 or -3 from the 3'-terminus, according to the principle described by Little (39). PCR, polymerase chain reaction; rs, reference single nucleotide polymorphism; $\mathrm{F}$, forward; R, reverse; Ta, annealing temperature; bp, base pairs.

A locus rs1057451 polymorphism

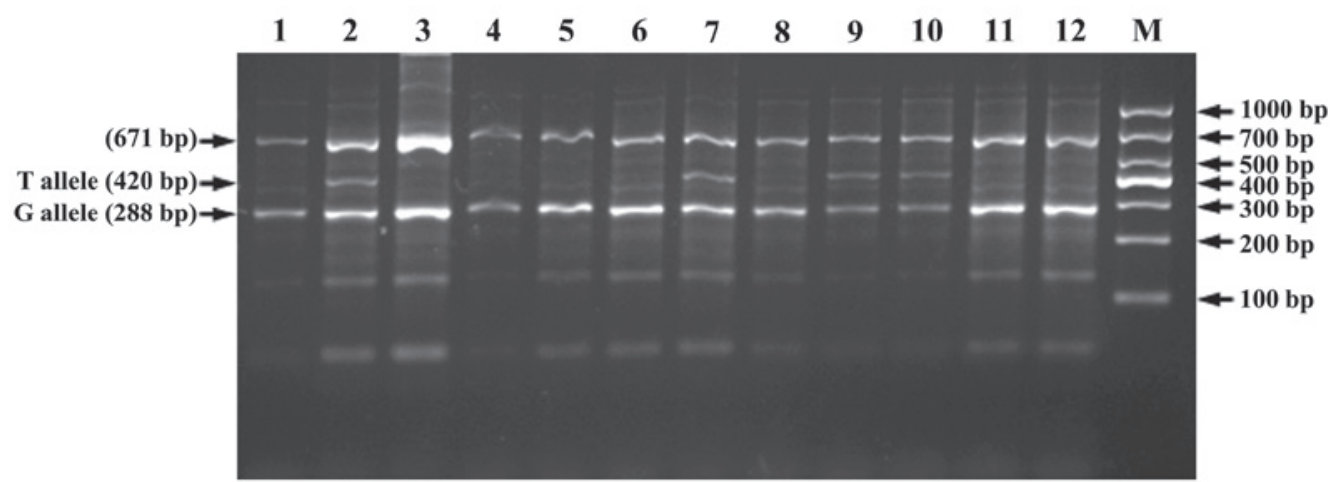

GG GT GG GG GG GG GT GG GT GT GG GG

$\mathbf{B}$

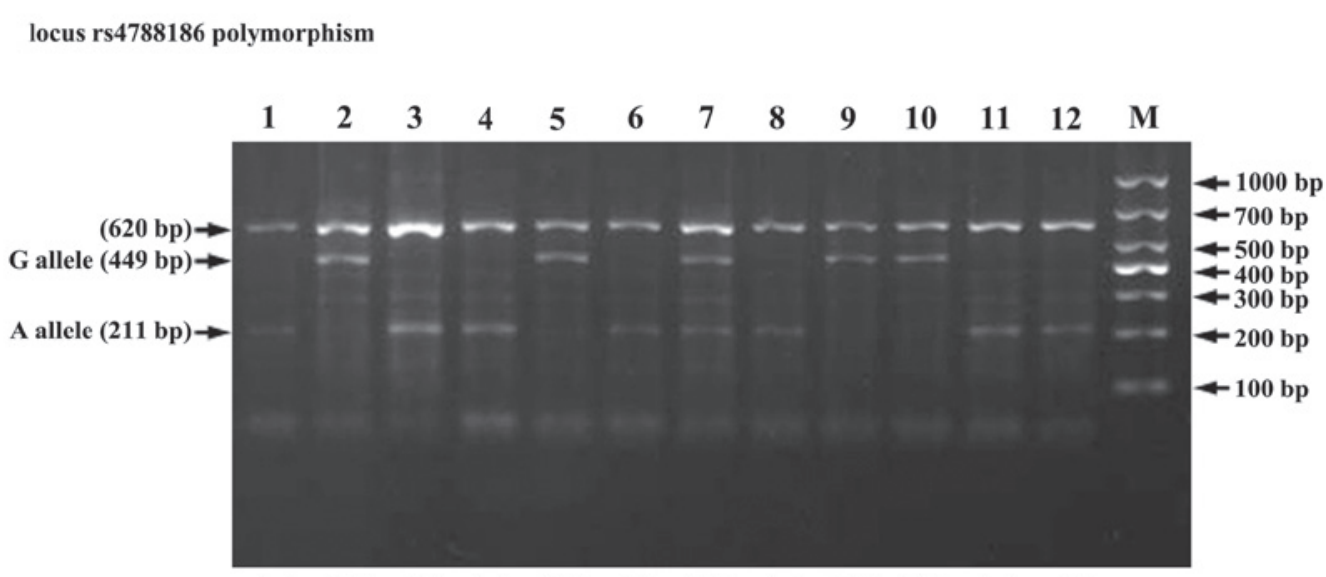

AA GG AA AA GG AA AG AA GG GG AA AA

Figure 1. Results of tetra-primer amplification refractory mutation system-polymerase chain reaction for (A) locus rs1057451 polymorphism and (B) locus rs4788186 polymorphism. The extra bands not marked with an arrow represent nonspecific amplification. M, DL1,000 DNA marker; bp, base pairs; rs, reference single nucleotide polymorphism. 
A
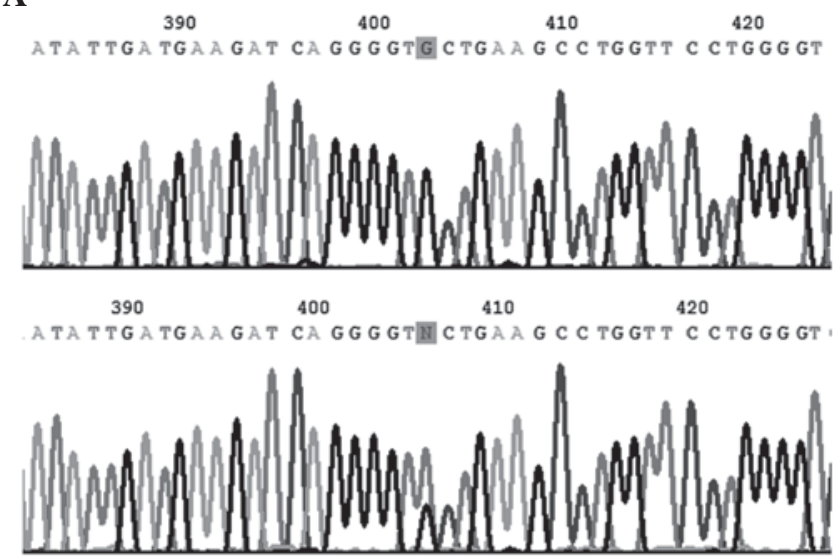

B
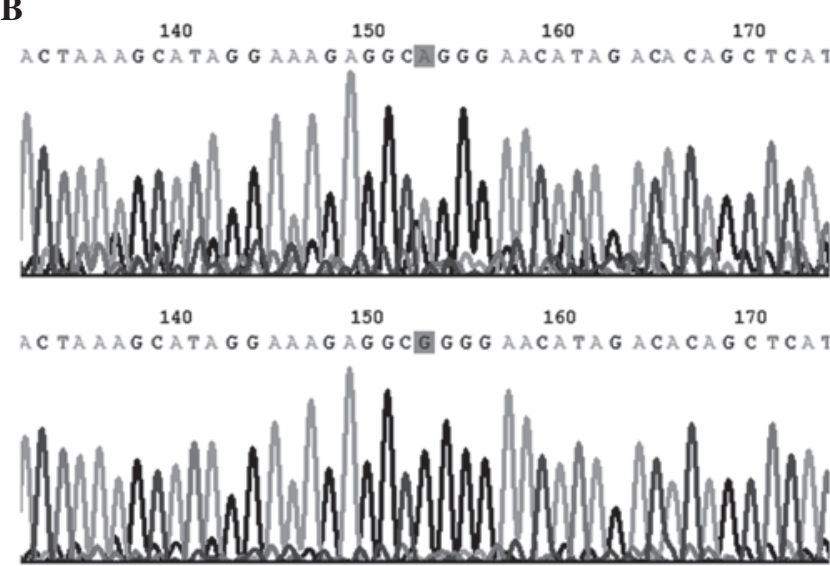

140

150

160

170
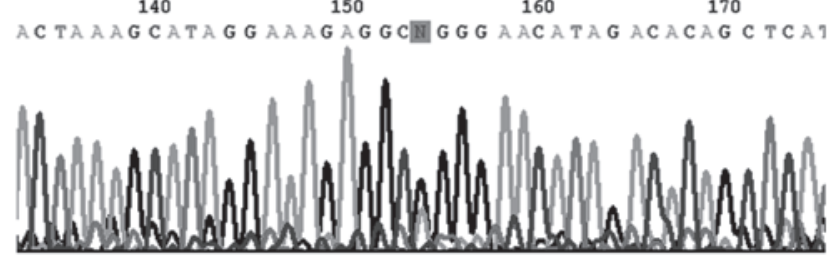

Figure 2. Results of DNA sequencing. The highlighted region in the chromatogram represents the polymorphic nucleotide. (A) Locus rs1057451 polymorphism. (B) Locus rs4788186 polymorphism. rs, reference single nucleotide polymorphism.

Direct Cycle Sequencing kit; BigDye Terminator 5X Sequencing Buffer and Hi-Di Formamide (all purchased from Invitrogen; Thermo Fisher Scientific, Inc., Waltham, MA, USA); the equipment used was a 3730xl DNA Analyzer (Applied Biosystems)], using their respective forward outer primers as sequencing primers, with the exception of rs1057451, whose sequence differs from the others, since it contains two poly-deoxyribonucleotide structures between the two outer primers. Therefore, in order to avoid those structures, another reverse primer was designed for DNA sequencing purposes (Table I). The reverse complement sequence is presented in Fig. 2A.

Statistics. The association between each polymorphism and the clinicopathological parameters of the patients was assessed by Pearson's $\chi^{2}$ test or Fisher's exact test. The allele and genotype distribution of the investigated SNPs in platinum-resistant and platinum-responsive cohorts was compared using Pearson's $\chi^{2}$ test
Table II. Clinicopathological parameters of 116 patients with epithelial ovarian cancer.

\begin{tabular}{lc}
\hline Characteristics & No. $(\%)$ \\
\hline Age at diagnosis, years & \\
$\leq 50$ & $53(45.7)$ \\
$>50$ & $63(54.3)$ \\
FIGO stage & \\
I & $8(6.9)$ \\
II & $17(14.7)$ \\
III & $57(49.1)$ \\
IV & $34(29.3)$
\end{tabular}

Tumor grade

G1

G2

G3

Unknown

Histological type

Serous

Mucinous

Endometrioid

Clear cell

Other ${ }^{\mathrm{a}}$

Chemotherapy regimen

TAX+DDP

$\mathrm{TAX}+\mathrm{CBP}$

TXT+DDP

$\mathrm{TXT}+\mathrm{CBP}$

Other platinum-based regimen

Chemotherapy response

Resistance

Sensitivity

${ }^{\mathrm{a} O t h e r ~ h i s t o l o g i c a l ~ t y p e s ~ o f ~ e p i t h e l i a l ~ o v a r i a n ~ c a n c e r ~ i n c l u d e d ~ u n d i f-~}$ ferentiated and transitional cell carcinoma. TAX, taxol; TXT, taxetere; DDP, cisplatin; CBP, carboplatin; FIGO, International Federation of Gynecology and Obstetrics.

or Fisher's exact test. The combined effect of the polymorphisms on tumor response was investigated by haplotype analysis using the SHEsis software platform (date of access, November 3, 2014), which is available at http://analysis.bio-x.cn/myAnalysis. php (40). Univariate survival analysis was determined using the Kaplan-Meier method, and survival curves were compared by log-rank test. Multivariate survival analysis was performed by the Cox proportional hazards regression model to adjust for tumor stage, histological type and chemotherapy response. Statistical analyses were performed using SPSS 13.0 software (SPSS, Inc., Chicago, IL, USA). All statistics were two-sided, and $\mathrm{P}<0.05$ was considered to indicate a statistically significant difference.

\section{Results}

Genotyping by tetra-primer ARMS-PCR. The tetra-primer ARMS-PCR method was successfully applied to genotype the 
Table III. Genotype and allele frequencies of polymorphisms of the major vault protein gene in platinum-resistant and platinum-responsive cohorts.

\begin{tabular}{lccr}
\hline Polymorphism & Non-responder, no. $(\%)$ & Responder, no. $(\%)$ & \\
\hline rs1057451 & & & \\
GG & $26(83.9)$ & $9(89.4)$ & 0.520 \\
GT & $5(16.1)$ & $161(94.7)$ & 0.520 \\
G & $57(91.9)$ & $9(5.3)$ & 0.533 \\
T & $5(8.1)$ & & 0.533 \\
rs4788186 & & $48(56.5)$ \\
AA & $15(48.4)$ & $32(37.6)$ \\
AG & $13(41.9)$ & $5(5.9)$ & $37(43.5)$ \\
GG & $3(9.7)$ & $80(94.1)$ & 0.606 \\
AG+GG & $16(51.6)$ & $128(75.3)$ & 0.606 \\
AA+AG & $28(90.3)$ & $42(24.7)$ & 0.606 \\
A & $43(69.4)$ & 0.439 \\
G & $19(30.6)$ & 0.439 \\
\hline
\end{tabular}

rs, reference single nucleotide polymorphism.

Table IV. Major vault protein gene haplotypes and patients' response to platinum chemotherapy.

\begin{tabular}{lccc}
\hline Haplotypes $^{\mathrm{a}}$ & Responder (frequency) & Non-responder (frequency) & OR (95\% CI) \\
\hline GA & $128(0.753)$ & $43(0.694)$ & $1.347(0.708-2.561)$ \\
GG & $33(0.194)$ & $14(0.226)$ & $0.826(0.408-1.674)$ \\
TA & $0(0.000)$ & $0(0.000)$ & - \\
TG & $9(0.053)$ & $5(0.081)$ & $0.637(0.205-1.981)$ \\
\hline
\end{tabular}

${ }^{a}$ Haplotypes whose frequency was $<0.03$ were ignored in the analysis. The order of the polymorphisms was rs 1057451 , rs 4788186 , and indicates the Chromosome Reference Sequence from the SNP database of National Center for Biotechnology Information. Global $\chi^{2}=1.020$, $\mathrm{df}=2, \mathrm{P}=0.600$. OR, odds ratio; CI, confidence interval; rs, reference single nucleotide polymorphism; df, degrees of freedom.

Table V. Multivariate survival analysis by Cox proportional hazards regression model.

\begin{tabular}{|c|c|c|c|c|c|c|c|}
\hline \multirow[b]{2}{*}{ Polymorphism } & \multirow[b]{2}{*}{ Genotype } & \multicolumn{3}{|c|}{ Progression-free survival } & \multicolumn{3}{|c|}{ Overall survival } \\
\hline & & HR & $95 \% \mathrm{CI}$ & P-value & HR & $95 \% \mathrm{CI}$ & P-value \\
\hline \multirow[t]{2}{*}{ rs1057451 } & GG & Reference & - & - & Reference & - & - \\
\hline & GT & 0.508 & $0.226-1.143$ & 0.102 & 0.586 & $0.245-1.405$ & 0.231 \\
\hline \multirow[t]{7}{*}{ rs4788186 } & $\mathrm{AA}$ & Reference & - & - & Reference & - & - \\
\hline & $\mathrm{AG}$ & 0.600 & $0.358-1.007$ & 0.053 & 0.803 & $0.482-1.337$ & 0.399 \\
\hline & GG & 0.936 & $0.386-2.270$ & 0.883 & 1.037 & $0.427-2.516$ & 0.937 \\
\hline & AA & Reference & - & - & Reference & - & - \\
\hline & $\mathrm{AG}+\mathrm{GG}$ & 0.650 & $0.402-1.051$ & 0.079 & 0.839 & $0.519-1.356$ & 0.474 \\
\hline & GG & Reference & - & - & Reference & - & - \\
\hline & $\mathrm{AA}+\mathrm{AG}$ & 0.888 & $0.370-2.129$ & 0.790 & 0.882 & $0.371-2.093$ & 0.775 \\
\hline
\end{tabular}

HR, hazard ratio; CI, confidence interval; rs, reference single nucleotide polymorphism.

selected SNPs (Fig. 1). The results from DNA sequencing were consistent with those from tetra-primer ARMS-PCR (Fig. 2).
Genotype frequency distribution of the two polymorphisms and their association with clinicopathological parameters. 
A

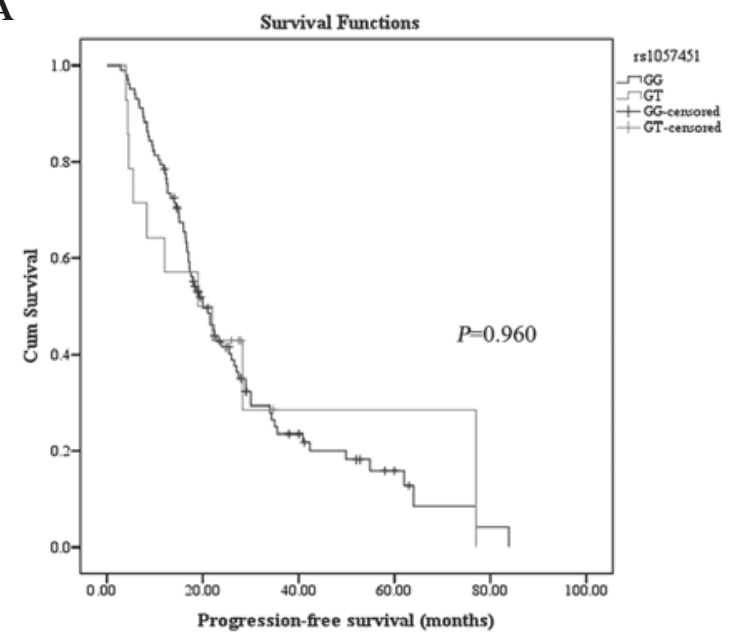

B

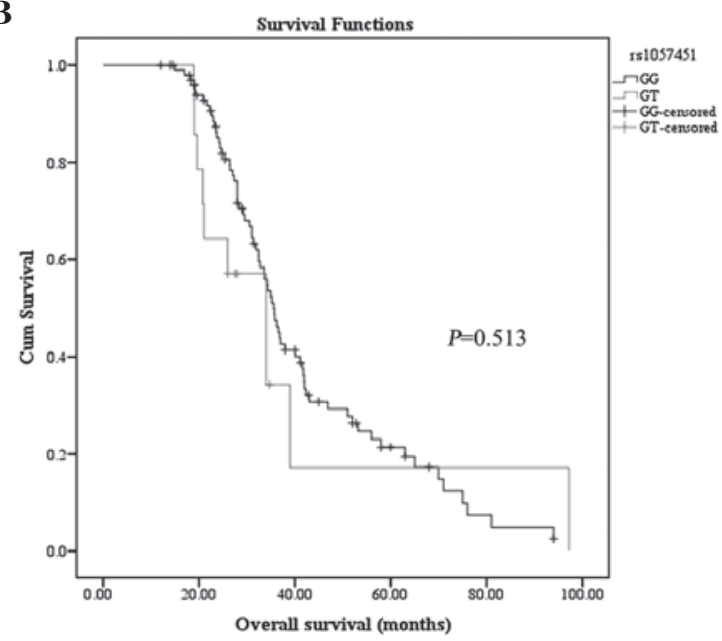

Figure 3. Kaplan-Meier analysis of (A) progression-free survival and (B) overall survival classified by the rs1057451 polymorphism in the major vault protein gene. Cum, cumulative; rs, reference single nucleotide polymorphism.

A

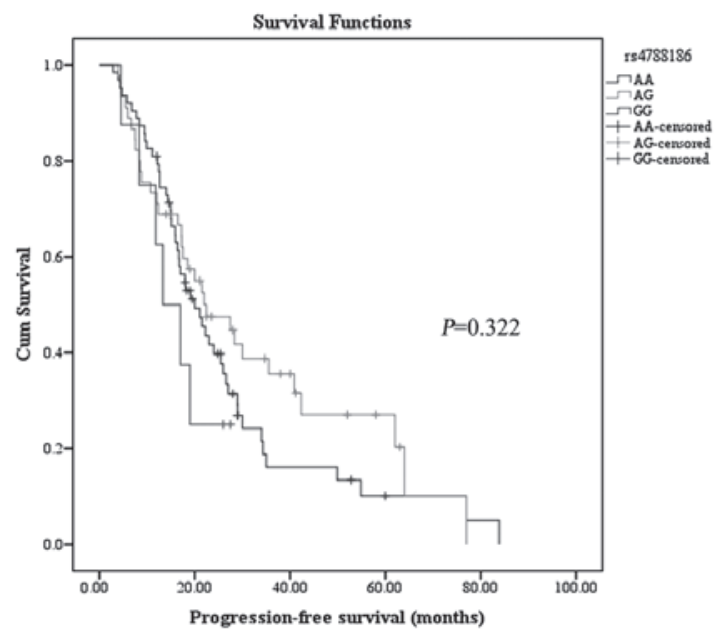

B

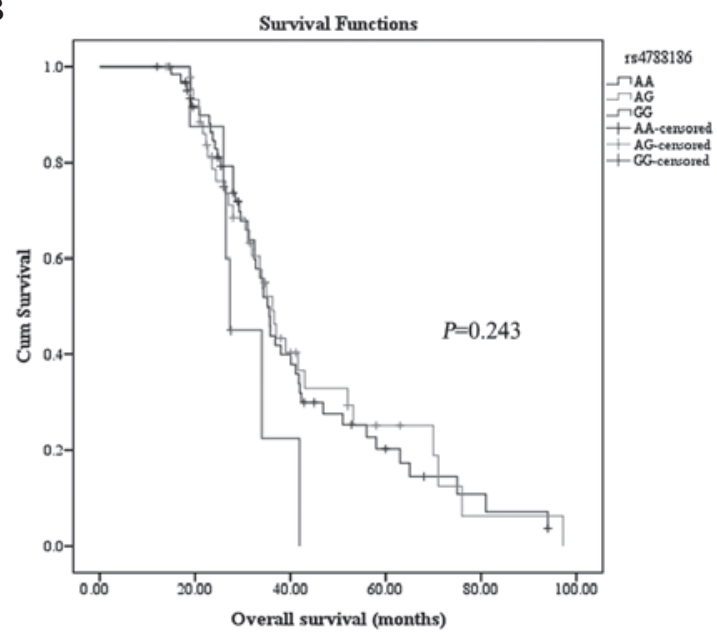

Figure 4. Kaplan-Meier analysis of (A) progression-free survival and (B) overall survival classified by the rs4788186 polymorphism in the major vault protein gene. Cum, cumulative; rs, reference single nucleotide polymorphism.

The clinicopathological parameters, including the FIGO stage (41) of the patients are summarized in Table II. Polymorphism of locus rs2288043 was not analyzed, since the mutant allele for this locus was absent in the patients selected for the present study. By contrast, the other two polymorphisms, rs1057451 and rs4788186, were evaluated. The genotype frequencies in the studied patient population were as follows: MVP locus rs1057451, 87.9\% GG and $12.1 \%$ GT; and MVP locus rs $4788186,54.3 \%$ AA, 38.8\% GA and 6.9\% GG. Neither of these two polymorphisms in the MVP gene was associated with age or tumor stage, grade or histological type (data not shown). The overall response rate of platinum-based chemotherapy was $73.3 \%$, with no significant difference in response rate among all platinum-based regimens (Fisher's exact test, $\mathrm{P}=0.696)$ (data not shown).

Association between the two polymorphisms and platinum resistance. There was no significant difference in genotype and allele distributions of the studied SNPs between platinum-resistant and platinum-responsive patients (Table III). Additionally, haplotype analysis did not reveal any association between haplotypes and platinum resistance (Table IV).

Association between rs1057451 polymorphism and survival. None of the patients was observed to be homozygous for the minor TT allele. Univariate Kaplan-Meier analysis demonstrated that PFS did not differ between patients carrying the GG genotype and those carrying the GT genotype (log-rank test, $\mathrm{P}=0.960$; Fig. 3A). OS did not differ either between the two genotypes ( $\mathrm{P}=0.513$, Fig. 3B). When adjusting for other potential confounding variables in a multivariate $\mathrm{Cox}$ regression model, the locus rs1057451 polymorphism had no significant predictive value for PFS $(\mathrm{P}=0.102$; Table $\mathrm{V})$ or OS $(\mathrm{P}=0.231$; Table V).

Association between rs 4788186 polymorphism and survival. Kaplan-Meier analysis of the rs 4788186 polymorphism did 
not reveal a significant difference in PFS between genotypes AA, AG and GG ( $\mathrm{P}=0.322$; Fig. 4A). Similar trends were observed in OS for these genotypes at this locus $(\mathrm{P}=0.243$; Fig. 4B). When the AG and GG subgroups were combined, the log-rank test failed to detect any significant difference in PFS (log-rank test, $\mathrm{P}=0.453$ ) or OS (log-rank test, $\mathrm{P}=0.905)$. There was no statistically significant difference in PFS (log-rank test, $\mathrm{P}=0.278$ ) or $\mathrm{OS}$ (log-rank test, $\mathrm{P}=0.097$ ) between patients carrying the GG genotype and those carrying a non-GG genotype (data not shown). Multivariate Cox regression analysis revealed that rs4788186 variants were neither associated with PFS nor with OS, once adjusted by International Federation of Gynecology and Obstetrics stage, histological type and chemotherapeutic response (Table V), although a trend toward reduced risk of progression was observed for patients with the AG genotype, compared with those exhibiting the AA genotype (hazard ratio, $0.600 ; 95 \%$ confidence interval, 0.358-1.007; $\mathrm{P}=0.053$; Table V). The multivariate survival analysis performed for genotypes AG and GG, compared with the major AA genotype, did not reveal any statistically significant difference in PFS or OS (Table V). Comparison of PFS and OS between patients with the GG genotype and those with a non-GG genotype did not reveal any significant difference (Table V).

\section{Discussion}

MVP is considered to be important in the treatment response and prognosis of various tumors $(22,23,42)$. The majority of clinical studies published to date have evaluated the mRNA or protein levels of MVP in order to investigate the association of MVP with platinum resistance and survival in EOC $(22,43)$. To the best of our knowledge, there are no previous studies on the association between genetic variants of the MVP gene and platinum resistance in patients with EOC. To investigate the role of MVP polymorphisms in predicting platinum response and survival, three SNPs from the genotype data derived from the phase II HapMap Project of Han Chinese population were selected in the present study. The results indicated that the mutant allele for locus rs2288043 was not present in any of the patients enrolled in the study, and neither platinum resistance nor survival were associated with the other two polymorphisms (rs1057451 and rs4788186).

These findings may be explained by the following factors: Firstly, it is important to remember that MDR is certainly involved in various mechanisms (44). Thus, the complex mechanisms involved in MDR may represent one of the obstacles in predicting the treatment response and survival by merely several genetic polymorphisms. Secondly, although MVP has been previously implicated in drug resistance, several studies have reported conflicting results $(45,46)$. Certain studies have demonstrated that MVP has no influence on intracellular drug distribution or chemoresistance (47-50). Similarly, Siva et al (51) demonstrated that the upregulation of MVP is not sufficient to confer an MDR phenotype. In addition, recent studies have correlated MVP with several signaling pathways (52-56) and immune responses (57-60), which imply that the function of MVP may be more complex than expected. Thirdly, the inability to find an association between variants of the MVP gene and platinum resistance or survival in the present study may be due to the limited number of patients enrolled in the study, since the number of patients in the subgroup was below the statistical threshold. Therefore, to demonstrate the independent effect of the aforementioned polymorphisms on the chemotherapy response and prognosis of patients with EOC, a large and homogeneous cohort of patients, such as advanced stage cases following optimal cytoreductive surgery, may be required. Finally, the absence of correlations observed in the present study may be due to the SNPs selected, which may not tag the SNPs responsible for the upregulation of the protein levels of MVP.

The tetra-primer ARMS-PCR method applied in the present study is more cost- and time-effective than other commonly used genotyping methods such as PCR-restriction fragment length polymorphism and TaqMan assays $(61,62)$. In addition, the tetra-primer ARMS-PCR method has also been demonstrated to possess a high reliability in genotyping $(38,61,62)$, thus it may be used for detecting polymorphisms. The limitations of the present study were the absence of subgroups analysis due to the small number of patients participating in the study, and the absence of toxicity analysis.

In conclusion, no associations between the two polymorphisms in the MVP gene analyzed in the present study and platinum-resistance or survival were observed in the patients with EOC who were recruited for the study. Furthermore, the present study has demonstrated that tetra-primer ARMS-PCR is a reliable method for genotyping.

\section{Acknowledgements}

The present study was supported by funds from the Natural Science Foundation of Liaoning Province (Shenyang, China; grant no. 2014022011) and the Medical Peak Construction Project of Liaoning Province (Shenyang, China).

\section{References}

1. Jemal A, Bray F, Center MM, Ferlay J, Ward E and Forman D: Global cancer statistics. CA Cancer J Clin 61: 69-90, 2011.

2. Omura G, Blessing JA, Ehrlich CE, Miller A, Yordan E, Creasman WT and Homesley HD: A randomized trial of cyclophosphamide and doxorubicin with or without cisplatin in advanced ovarian carcinoma. A Gynecologic Oncology Group Study. Cancer 57: 1725-1730, 1986.

3. Omura GA, Bundy BN, Berek JS, Curry S, Delgado G and Mortel R: Randomized trial of cyclophosphamide plus cisplatin with or without doxorubicin in ovarian carcinoma: A Gynecologic Oncology Group Study. J Clin Oncol 7: 457-465, 1989.

4. Aabo K, Adams M, Adnitt P, Alberts DS, Athanazziou A, Barley V, Bell DR, Bianchi U, Bolis G, Brady MF, et al: Chemotherapy in advanced ovarian cancer: Four systematic meta-analyses of individual patient data from 37 randomized trials. Advanced Ovarian Cancer Trialists' Group. Br J Cancer 78: 1479-1487, 1998

5. Trimbos JB, Parmar M, Vergote I, Guthrie D, Bolis G, Colombo N, Vermorken JB, Torri V, Mangioni C, Pecorelli S, et al; European Organisation for Research and Treatment of Cancer Collaborators - Adjuvant ChemoTherapy In Ovarian Neoplasm: International Collaborative Ovarian Neoplasm trial 1 and Adjuvant ChemoTherapy In Ovarian Neoplasm trial: Two parallel randomized phase III trials of adjuvant chemotherapy in patients with early-stage ovarian carcinoma. J Natl Cancer Inst 95: 105-112, 2003.

6. Bookman MA: Developmental chemotherapy and management of recurrent ovarian cancer. J Clin Oncol 21 (Suppl 10): 149s-167s, 2003.

7. Modesitt SC and Jazaeri AA: Recurrent epithelial ovarian cancer: Pharmacotherapy and novel therapeutics. Expert Opin Pharmacother 8: 2293-2305, 2007. 
8. Biedler JL and Riehm H: Cellular resistance to actinomycin D in Chinese hamster cells in vitro: Cross-resistance, radioautographic, and cytogenetic studies. Cancer Res 30: 1174-1184, 1970

9. Fojo A, Hamilton TC, Young RC and Ozols RF: Multidrug resistance in ovarian cancer. Cancer 60 (Suppl): 2075-2080, 1987.

10. Scheffer GL, Schroeijers AB, Izquierdo MA, Wiemer EA and Scheper RJ: Lung resistance-related protein/major vault protein and vaults in multidrug-resistant cancer. Curr Opin Oncol 12: $550-556,2000$

11. Teodori E, Dei S, Martelli C, Scapecchi S and Gualtieri F: The functions and structure of ABC transporters: Implications for the design of new inhibitors of Pgp and MRP1 to control multidrug resistance (MDR). Curr Drug Targets 7: 893-909, 2006.

12. Roy S, Kenny E, Kennedy S, Larkin A, Ballot J, Perez De Villarreal M, Crown J and O'Driscoll L: MDR1/P-glycoprotein and MRP-1 mRNA and protein expression in non-small cell lung cancer. Anticancer Res 27: 1325-1330, 2007.

13. Ahmad A, Robinson AR, Duensing A, van Drunen E, Beverloo HB, Weisberg DB, Hasty P, Hoeijmakers JH and Niedernhofer LJ: ERCC1-XPF endonuclease facilitates DNA double-strand break repair. Mol Cell Biol 28: 5082-5092, 2008.

14. Arora S, Kothandapani A, Tillison K, Kalman-Maltese V and Patrick SM: Downregulation of XPF-ERCC1 enhances cisplatin efficacy in cancer cells. DNA Repair 9: 745-753, 2010.

15. Kim R, Tanabe K, Uchida Y, Emi M, Inoue H and Toge T: Current status of the molecular mechanisms of anticancer drug-induced apoptosis. The contribution of molecular-level analysis to cancer chemotherapy. Cancer Chemother Pharmacol 50: 343-352, 2002.

16. Johnstone RW, Cretney E and Smyth MJ: P-glycoprotein protects leukemia cells against caspase-dependent, but not caspase-independent, cell death. Blood 93: 1075-1085, 1999.

17. Maugeri-Saccà $M$, Vigneri $P$ and De Maria R: Cancer stem cells and chemosensitivity. Clin Cancer Res 17: 4942-4947, 2011

18. Castells M, Thibault B, Delord JP and Couderc B: Implication of tumor microenvironment in chemoresistance: Tumor-associated stromal cells protect tumor cells from cell death. Int J Mol Sci 13 9545-9571, 2012

19. Hanahan D and Weinberg RA: Hallmarks of cancer: The next generation. Cell 144: 646-674, 2011

20. Hanahan D and Coussens LM: Accessories to the crime: Functions of cells recruited to the tumor microenvironment Cancer Cell 21: 309-322, 2012.

21. Scheffer GL, Wijngaard PL, Flens MJ, Izquierdo MA, Slovak ML, Pinedo HM, Meijer CJ, Clevers HC and Scheper RJ: The drug resistance-related protein LRP is the human major vault protein. Nat Med 1: 578-582, 1995.

22. Kerr EH, Frederick PJ, Egger ME, Stockard CR, Sellers J, DellaManna D, Oelschlager DK, Amm HM, Eltoum IE, Straughn JM, et al: Lung resistance-related protein (LRP) expression in malignant ascitic cells as a prognostic marker for advanced ovarian serous carcinoma. Ann Surg Oncol 20: 30593065,2013

23. Chen ZJ, Le HB, Zhang YK, Qian LY, Sekhar KR and Li WD: Lung resistance protein and multidrug resistance protein in non-small cell lung cancer and their clinical significance. J Int Med Res 39: 1693-1700, 2011.

24. Han M, Lv Q, Tang XJ, Hu YL, Xu DH, Li FZ, Liang WQ and Gao JQ: Overcoming drug resistance of MCF-7/ADR cells by altering intracellular distribution of doxorubicin via MVP knockdown with a novel siRNA polyamidoamine-hyaluronic acid complex. J Control Release 163: 136-144, 2012.

25. Kedersha NL, Hill DF, Kronquist KE and Rome LH: Subpopulations of liver coated vesicles resolved by preparative agarose gel electrophoresis. J Cell Biol 103: 287-297, 1986.

26. Kickhoefer VA, Searles RP, Kedersha NL, Garber ME, Johnson DL and Rome LH: Vault ribonucleoprotein particles from rat and bullfrog contain a related small RNA that is transcribed by RNA polymerase III. J Biol Chem 268: 7868-7873, 1993

27. Kickhoefer VA, Siva AC, Kedersha NL, Inman EM, Ruland C, Streuli M and Rome LH: The $193-\mathrm{kD}$ vault protein, VPARP, is a novel poly(ADP-ribose) polymerase. J Cell Biol 146: 917-928, 1999

28. Kickhoefer VA, Stephen AG, Harrington L, Robinson MO and Rome LH: Vaults and telomerase share a common subunit, TEP1. J Biol Chem 274: 32712-32717, 1999.

29. Izquierdo MA, Scheffer GL, Flens MJ, Giaccone G Broxterman HJ, Meijer CJ, van der Valk P and Scheper RJ: Broad distribution of the multidrug resistance-related vault lung resistance protein in normal human tissues and tumors. Am J Pathol 148: 877-887, 1996.
30. List AF, Spier CS, Grogan TM, Johnson C, Roe DJ, Greer JP, Wolff SN, Broxterman HJ, Scheffer GL, Scheper RJ and Dalton WS: Overexpression of the major vault transporter protein lung-resistance protein predicts treatment outcome in acute myeloid leukemia. Blood 87: 2464-2469, 1996.

31. Henríquez-Hernández LA, Moreno M, Rey A, Lloret M and Lara PC: MVP expression in the prediction of clinical outcome of locally advanced oral squamous cell carcinoma patients treated with radiotherapy. Radiat Oncol 7: 147, 2012.

32. Li J, Li ZN, Yu LC, Bao QL, Wu JR, Shi SB and Li XQ Association of expression of MRP1, BCRP, LRP and ERCC1 with outcome of patients with locally advanced non-small cell lung cancer who received neoadjuvant chemotherapy. Lung Cancer 69: 116-122, 2010

33. Lu S, Pardini B, Cheng B, Naccarati A, Huhn S, Vymetalkova V, Vodickova L, Buchler T, Hemminki K, Vodicka P and Försti A: Single nucleotide polymorphisms within interferon signaling pathway genes are associated with colorectal cancer susceptibility and survival. PLoS One 9: e111061, 2014.

34. Bosó V, Herrero MJ, Santaballa A, Palomar L, Megias JE de la Cueva H, Rojas L, Marqués MR, Poveda JL, Montalar J and Aliño SF: SNPs and taxane toxicity in breast cancer patients. Pharmacogenomics 15: 1845-1858, 2014.

35. Du Y, Su T, Zhao L, Tan X, Chang W, Zhang H and Cao G: Associations of polymorphisms in DNA repair genes and MDR gene with chemotherapy response and survival of non-small cell lung cancer. PLoS One 9: e99843, 2014.

36. Mendoza J, Martínez J, Hernández C, Pérez-Montiel D, Castro C, Fabián-Morales E, Santibáñez M, González-Barrios R, Díaz-Chávez J, Andonegui MA, et al: Association between ERCC1 and XPA expression and polymorphisms and the response to cisplatin in testicular germ cell tumours. Br J Cancer 109: $68-75,2013$

37. Cannistra SA, Matulonis UA, Penson RT, Hambleton J, Dupont J, Mackey H, Douglas J, Burger RA, Armstrong D, Wenham R and McGuire W: Phase II study of bevacizumab in patients with platinum-resistant ovarian cancer or peritoneal serous cancer. J Clin Oncol 25: 5180-5186, 2007.

38. Ye S, Dhillon S, Ke X, Collins AR and Day IN: An efficient procedure for genotyping single nucleotide polymorphisms. Nucleic Acids Res 29: E88-E89, 2001.

39. Little S: ARMS analysis of point mutations. In: Laboratory Methods for the Detection of Mutations and Polymorphisms in DNA. Taylor GR (ed). CRC Press, Boca Raton, FL, pp45-51, 1997.

40. Shi YY and He L: SHEsis, a powerful software platform for analyses of linkage disequilibrium, haplotype construction and genetic association at polymorphism loci. Cell Res 15: 97-98, 2005.

41. Mutch DG and Prat J: 2014 FIGO staging for ovarian, fallopian tube and peritoneal cancer. Gynecol Oncol 133: 401-404, 2014.

42. Filipits M, Pohl G, Stranzl T, Suchomel RW, Scheper RJ, Jäger U, Geissler K, Lechner K and Pirker R: Expression of the lung resistance protein predicts poor outcome in de novo acute myeloid leukemia. Blood 91: 1508-1513, 1998.

43. Szaflarski W,Sujka-Kordowska P,Pula B,Jaszczyńska-Nowinka K, Andrzejewska M, Zawierucha P, Dziegiel P, Nowicki M, Ivanov P and Zabel M: Expression profiles of vault components MVP, TEP1 and VPARP and their correlation to other multidrug resistance proteins in ovarian cancer. Int J Oncol 43: 513-520, 2013.

44. Baguley BC: Multiple drug resistance mechanisms in cancer. Mol Biotechnol 46: 308-316, 2010

45. Goff BA, Paley PJ, Greer BE and Gown AM: Evaluation of chemoresistance markers in women with epithelial ovarian carcinoma. Gynecol Oncol 81: 18-24, 2001.

46. Sedláková I, Laco J, Caltová K, Červinka M, Tošner J, Řezáč A and Špaček J: Clinical significance of the resistance proteins LRP, Pgp, MRP1, MRP3, and MRP5 in epithelialovarian cancer. Int J Gynecol Cancer 25: 236-243, 2015.

47. Mossink MH, van Zon A, Fränzel-Luiten E, Schoester M, Kickhoefer VA, Scheffer GL, Scheper RJ, Sonneveld P and Wiemer EA: Disruption of the murine major vault protein (MVP/LRP) gene does not induce hypersensitivity to cytostatics. Cancer Res 62: 7298-7304, 2002.

48. van Zon A, Mossink MH, Schoester M, Scheper RJ, Sonneveld P and Wiemer EAC: Efflux kinetics and intracellular distribution of daunorubicin are not affected by major vault protein/lung resistance-related protein (vault) expression. Cancer Res 64: 4887-4892, 2004.

49. Huffman KE and Corey DR: Major vault protein does not play a role in chemoresistance or drug localization in a non-small cell lung cancer cell line. Biochemistry 44: 2253-2261, 2005. 
50. Balan S, Radhab SK, Sathyan S, Vijai J, Banerjee $M$ and Radhakrishnan K: Major vault protein (MVP) gene polymorphisms and drug resistance in mesial temporal lobe epilepsy with hippocampal sclerosis. Gene 526: 449-453, 2013.

51. Siva AC, Raval-Fernandes S, Stephen AG, LaFemina MJ, Scheper RJ, Kickhoefer VA and Rome LH: Up-regulation of vaults may be necessary but not sufficient for multidrug resistance. Int J Cancer 92: 195-202, 2001.

52. Yu Z, Fotouhi-Ardakani N, Wu L, Maoui M, Wang S, Banville D and Shen SH: PTEN associates with the vault particles in HeLa cells. J Biol Chem 277: 40247-40252, 2002.

53. Steiner E, Holzmann K, Pirker C, Elbling L, Micksche M, Sutterlüty $\mathrm{H}$ and Berger $\mathrm{W}$ : The major vault protein is responsive to and interferes with interferon-gamma-mediated STAT1 signals. J Cell Sci 119: 459-469, 2006.

54. Losert A, Lötsch D, Lackner A, Koppensteiner H, Peter-Vörösmarty B, Steiner E, Holzmann K, Grunt T, Schmid K, Marian B, et al: The major vault protein mediates resistance to epidermal growth factor receptor inhibition in human hepatoma cells. Cancer Lett 319: 164-172, 2012.

55. Lötsch D, Steiner E, Holzmann K, Spiegl-Kreinecker S, Pirker C, Hlavaty J, Petznek H, Hegedus B, Garay T, Mohr T, et al: Major vault protein supports glioblastoma survival and migration by upregulating the EGFR/PI3K signalling axis. Oncotarget 4: 1904-1918, 2013

56. Tomiyasu H, Watanabe M, Goto-Koshino Y, Fujino Y, Ohno K, Sugano S and Tsujimoto H: Regulation of expression of ABCB1 and LRP genes by mitogen-activated protein kinase/extracellular signal-regulated kinase pathway and its role in generation of side population cells in canine lymphoma cell lines. Leuk Lymphoma 54: 1309-1315, 2013.
57. Rivera-Rivera L, Perez-Laspiur J, Colón K and Meléndez LM: Inhibition of interferon response by cystatin B: Implication in HIV replication of macrophage reservoirs. J Neurovirol 18: 20-29, 2012.

58. Liu S, Peng N, Xie J, Hao Q, Zhang M, Zhang Y, Xia Z, $\mathrm{Xu} \mathrm{G}$, Zhao F, Wang Q, et al: Human hepatitis B virus surface and e antigens inhibit major vault protein signaling in interferon induction pathways. J Hepatol 62: 1015-1023, 2015.

59. Liu S, Hao Q, Peng N, Yue X, Wang Y, Chen Y, Wu J and Zhu Y: Major vault protein: A virus-induced host factor against viral replication through the induction of type-I interferon. Hepatology 56: 57-66, 2012.

60. Dortet L, Mostowy S, Samba-Louaka A, Gouin E, Nahori MA, Wiemer EA, Dussurget O and Cossart P: Recruitment of the major vault protein by InlK: A Listeria monocytogenes strategy to avoid autophagy. PLoS Pathog 7: e1002168, 2011.

61. Etlik O, Koksal V, Arican-Baris ST and Baris I: Development and validation of a cost-effective in-house method, tetra-primer ARMS PCR assay, in genotyping of seven clinically important point mutations. Mol Cell Probes 25: 177-181, 2011.

62. Miranzadeh-Mahabadi H, Miranzadeh-Mahabadi $\mathrm{H}$, Nikpour P, Emadi-Baygi M and Kelishadi R: Comparison of TaqMan real-time and tetra-primer ARMS PCR techniques for genotyping of Rs 8066560 variant in children and adolescents with metabolic syndrome. Adv Clin Exp Med 24: 951-955, 2015. 